\title{
PENGGUNAAN MULTIMEDIA ONLINE DALAM PEMBELAJARAN
}

\author{
A. MARJUNI, HAMZAH HARUN \\ Fakultas Tarbiyah dan Keguruan UIN Alauddin Makassar \\ Jl. HM. Yasin Limpo No. 36 Makassar \\ Email: h.marjunij@yahoo.com
}

\begin{abstract}
:
The use of technology and information as multimedia learning has a very strategic function. Media is seen as one of the factors that can improve the learning process because the media has strategic roles and functions that can directly or indirectly affect the motivation, interests, and attention of students. The function of multimedia in learning is to overcome the limitations of students' experiences, be able to transcend classroom boundaries, enable direct interaction between students and their environment, produce uniform observations, instill the basic concepts that are true, concrete, and realistic. Multimedia can arouse new desires and interests and arouse students' motivation to learn and provide an integral or comprehensive experience from the concrete to the abstract. The advantages of using multimedia in learning include being able to improve students' ability to understand an abstract concept more easily, in addition to the use of computer media in the form of multimedia can give a positive impression to the teacher because it can help teachers explain the contents of the lesson to students, streamline time, and increase students' motivation in learning.
\end{abstract}

Keywords: Multimedia Online, Learning

\section{PENDAHULUAN}

embelajaran dengan penggunaan multimedia pada hakekatnya adalah proses untuk dapat memecahkan masalah (problem solving). Untuk hidup, manusia memerlukan kemampuan untuk melihat dunia secara nyata yang penuh dengan masalah yang harus dipecahkan. Untuk hal tersebut diperlukan kemampuan menganalisis, mencari jalan mengatasinya, serta mencoba cara-cara pemecahan yang telah dirumuskan (trial and error) (Bukhori, 2007: 25). Pemecahan masalah ini dalam implementasinya, bukan kembali pada tatanan yang seperti semula, namun berupaya menciptakan sistem baru yang lebih baik. Sistem pembelajaran yang baik, sistem sosial masyarakat yang ideal sehingga dalam hal ini dibutuhkan kerja sama oleh seluruh komponen masyarakat. Pendidikan berintikan interaksi antara pendidik dengan peserta didik dalam upaya membantu peserta didik dalam menguasai tujuan-tujuan pendidikan. Interaksi pendidikan dapat berlangsung dalam lingkungan keluarga, sekolah, maupun masyarakat. Pendidikan dalam lingkungan sekolah lebih bersifat formal.

Guru sebagai pendidik ataupun pengajar merupakan faktor penentu kesuksesan setiap usaha pendidikan. Itulah sebabnya setiap perbincangan mengenai perbaharuan kurikilum, pengadaan alat-alat belajar sampai pada kriteria 
sumber daya manusia yang dihasilkan oleh usaha pendidikan, selalu bermuara pada guru. Hal ini menunjukkan betapa pentingnya peran guru dalam dunia pendidikan (Syah, 2012).

Kualitas pembelajaran dapat dipengaruhi oleh beberapa faktor antara lain peserta didik, guru mata pelajaran, kurikulum, metode pelajaran, sarana dan perasarana. Dalam sistem pembelajaran yang menempati posisi struktural dan sebagai ujung tombaknya adalah guru. Sebab gurulah yang terlibat langsung dalam upaya mempegaruhi, membina, dan mengembangkan kemampuan peserta didik supaya menjadi cerdas, terampil, dan bermoral tinggi serta berjiwa sosial sehingga mampu hidup mandiri sebagai mahluk sosial. Seorang guru dituntut untuk mempunyai berbagai keterampilan yang mendukung tugasnya dalam mengajar. Salah satu keterampilan tersebut adalah bagaimana seorang guru dapat menggunakan media pembelajaran.

Multimedia merupakan salah satu sumber belajar. Jenis media bermacammacam dari yang sederhana seperti media kartu, sampai yang modern seperti komputer, internet, LCD, dan lain-lain. Berdasarkan indera yang digunakan peserta didik dalam memanfaatkan media pembelajaran. Media dapat dibagi menjadi tiga yaitu media audio, media visual, dan media audiovisual (Sadiman, 1986: 19). Ketiga media tersebut digunakan dalam proses pendidikan di sekolah untuk membantu peserta didik dalam kegiatan belajar mengajar. Indera yang selalu digunakan peserta didik dalam menangkap materi pembelajaran adalah indera penglihatan dan pendengaran. Sedangkan indera yang lain mempunyai presentase yang kecil dibandingkan dengan indera penglihatan dan pendengaran. Bahkan ada kecenderungan untuk memanfaatkan indera penglihatan yang dipandu dengan rangsangan indera pendengaran. Media tersebut dapat berupa media audiovisual, yang menggunakan indera penglihatan dan indera pendengaran, juga merupakan media visual, yang menggunakan indera penglihatan dengan didukung dengan keterangan-keterangan dari pendidik (guru) untuk memperjelas materi yang dihubungkan dengan media yang digunakan.

\section{PEMBAHASAN}

\section{Pengertian Penggunaan Multimedia}

Istilah penggunaan multimedia muncul pertama kali di awal 1990 melalui media massa. Istilah ini dipakai untuk menyatukan teknologi digital dan analog di bidang intertainment, publising, communications, marketing, dan juga commercial. Multimedia merupakan penggabungan dua kata "multi" dan "media". Multi berarti "banyak" sedangkan media atau bentuk jamaknya medium berasal dari bahasa latin yang berarti “tengah, perantara, atau pengantar (Ashar, 2012: 75). Istilah perantara atau pengantar ini, menurut Bovee (Ashar, 2012: 75), digunakan karena fungsi media sebagai perantara atau pengantar suatu pesan dari sipengirim (sender) kepada sipenerima (receiver) pesan. 
Gayekski mendefinisikan penggunaan multimedia sebagai kumpulan media berbasisi komputer dan sistem komunikasi yang memiliki peran untuk membentuk teks, garfik, audio, video, dan sebagainya. Sedangkan obliger mendia komunikasi seperti teks, garafik, animasi, audio dan video dengan ciri-ciri interaktivitas komputer untuk menghasilkan suatu presentasi menarik (Munir, 2012: 2).

Seiring dengan perkembangan teknologi dan informasi, pemaknaan multimedia ini semakin bergeser pada aspek pengintegrasian sistem dan jaringan serta prosedur komunikasi dalam sebuah perangkat khusus, seperti TV, radio, komputer, notebook, inbook (Darmawan, 2012: 32).

Multimedia adalah gabungan lebih dari satu media dalam suatu bentuk komunikasi. Menurut Lancien, multimedia pada masa kini merujuk pada penggabungan dan pengintegrasian media, seperti teks, animasi, grafik, suara, video kedalam sistem komputer. Akhir-akhir ini konsep multimedia semakin populer dengan munculnya monitor komputer beresolusi tinggi, teknologi video dan suara serta usaha peningkatan memproses komputer pribadi. Sebagai contoh sekarang sudah terdapat komputer dekstop yang bisa merekam suara dan video, memanipulasi suara serta gambar untuk mendapatkan efek khusus, memadukan dan menghasilkan suara serta video, menghasilkan berbagai jenis grafik termasuk animasi, dan mengintegrasikan semua ini kedalam satu bentuk multimedia.

Multimedia merupakan gabungan data, suara, video, audio, animasi, grafik, teks dan bunyi-bunyian yang mana gabungan elemen-elemen tersebut mampu dipaparkan melalui komputer.

Menurut Gayeski, D.M. "Multimedia ialah satu sistem hubungan komunikasi interaktif melalui komputer yang mampu mencipta, menyimpan, memindahkan, dan mencapai kembali data dan maklumat dalam bentuk teks, grafik, animasi, dan sistem audio." Jeffcoate mendifinisikan multimedia sebagai suatu sistem yang menggunakan berbagai kaedah berkomunikasi (atau media) (Darmawan, 2012: 34).

Menurut Phelps pula, multimedia adalah kombinasi teks, video, suara dan animasi dalam sesebuah perisian komputer yang interaktif. Schurman mendefinisikan multimedia sebagai kombinasi grafik, animasi, teks, video dan bunyi dalam satu perisian yang direka bentuk yang mementingkan interaksi antara pengguna dan komputer. Komputer yang mempunyai perkakasan berupaya untuk melaksanakan perisian multimedia atau disebut juga sebagai komputer multimedia (Darmawan, 2012: 35).

Menurut Collin, Simon Multimedia merupakan sebuah persembahan, permainan atau aplikasi yang menggabungkan beberapa media yang berlainan. Sebuah komputer yang boleh menggunakan klip video, rakaman suara, imej, animasi dan teks serta pula boleh mengendalikan peranti-peranti seperti perekam video, pemain cakra video, pemacu CD-ROM, synthesizer dan juga kamera video. Multimedia dapat diartikan sebagai penggunaan beberapa media yang berbeda untuk menggabungkan dan menyampaikan informasi dalam bentuk text, audio, grafik, animasi, dan video (Darmawan, 2012: 36). 
Beberapa definisi menurut beberapa ahli: Kombinasi dari komputer dan video, Kombinasi dari tiga elemen: suara, gambar, dan teks, Kombinasi dari paling sedikit dua media input atau output. Media ini dapat berupa audio (suara, musik), animasi, video, teks, grafik dan gambar. Alat yang dapat menciptakan presentasi yang dinamis dan interaktif yang mengkombinasikan teks, grafik, animasi, audio dan video. Multimedia dalam konteks komputer menurut Hofstetter adalah: pemanfaatan komputer untuk membuat dan menggabungkan teks, grafik, audio, video, dengan menggunakan tool yang memungkinkan pemakai berinteraksi, berkreasi, dan berkomunikasi. Menurut Haffos multimedia adalah sebagai suatu sistem komputer yang terdiri dari perkakasan dan perisian yang memberikan kemudahan untuk membolehkan gambar, video, fotografi, grafik dan animasi, dipadukan dengan suara, teks data yang dikendalikan dengan program komputer. Sedangkan Jayant, Ackland, Lawarence dan Rabiner menyatakan bahwa mulimedia adalah asas teknologi komunikasi modern yang meliputi suara, teks, imej, video dan data.

Jadi, menurut penulis bahwa multimedia merupakan teknik baru dalam bidang komputer yang menggabungkan lebih dari satu media dalam suatu bentuk komunikasi yang meliputi teks, suara, grafik, animasi, dan video ke dalam sistem komputer.

\section{Prinsip Pemanfaatan Multimedia}

Bahan ajar multimedia adalah media pembelajaran yang berbasis teknologi multimedia. Pembelajaran yang menggunakan multimedia ini sudah cukup luas di dunia pendidikan, tidak hanya diperguruan tinggi, melainkan juga di sekolah-sekolah. Bahan ajar berbasis multimedia paling sederhana dan paling bnayak dipakai adalah bahan presentasi menggunakan powerpoint. Disamping itu, media interaktif juga sudah banyak dikembangkan. Dalam pembelajaran berbasis multimedia, peserta didik dapat mempelajari materi ajar dalam CD/VCD interaktif dilengkapi dengan kuis untuk latihan. Di sini pendidik menyusun bahan ajar dalam bentuk modul atau buku, kemudian dikonversi dalam bentuk atau format digital. Menggunakan CD interaktif, peserta didik dapat menggunakan secara berulang, individual atau kelompok hingga materinya dapat dipahami. Peserta didik juga melakukan evaluasi terhadap pencapaian belajar melalui kuis yang disediakan secara interaktif. Sebagaimana bahan ajar media lainnya, prinsip utama dalam pembuatan bahan ajar berbasis multimedia harus sesuai dengan sasaran dan tujuan pembelajaran serta materi ajar. Bahan ajar tersebut juga dapat berinteraksi dengan peserta didik dengan maupun tanpa bantuan guru. Artinya, bahan ajar tersebut dapat digunakan secara mandiri oleh peserta didik.

Setiap format bahan ajar multimedia memiliki karakteristik tertentu dan kriteria bahan pembelajaran multimedia yang baik ditentukan oleh karakteristiknya. Semua proses pembelajaran mulai pemilihan media, metode dan model pembelajaran saling mendukung dan melengkapi untuk memudahkan pemahaman peserta didik terhadap materi yang diajarkan. 


\section{Kriteria Multimedia dalam Pengembangan Pembelajaran}

Secara umum dapat digambarkan beberapa kriteria bahan ajar multimedia yang baik yaitu tampilan harus menarik baik dari sisi bentuk gambar maupun kombinasi warna yang digunakan, narasi atau bahasa harus jelas dan mudah dipahami oleh peserta didik. Penggunaan istilah perlu disesuaikan dengan pengguna media agar pembelajaran bisa efektif, materi disajikan secara interaktif, artinya memungkinkan partisipasi dari peserta didik, kebutuhan untuk mengakomodasi berbagai model (styles) yang berbeda dalam belajar, karakteristik dan budaya personal dari populasi yang akan dijadikan target, sesuai dengan karakteristik peserta didik, karakteristik materi dan tujuan yang ingin dicapai, dimungkinkan untuk digunakan sebagai salah satu media pembelajaran, dalam arti sesuai dengan sarana pendukung terdsedia, memungkinkan ditampilkan suatu virtual learning environment (lingkungan belajar virtual) seperti web-based application yang menunjang, dan proses pembelajaran adalah suatu kontinuitas utuh, bukan sporadik dan kejadian terpisah-pisah (Wijaya, http://media-grafika.com/pengertian-mediapembelajaran).

\section{Aplikasi Pembelajaran Interaktif}

Aplikasi adalah program yang memiliki aktivitas pemrosesan perintah yang diperlukan untuk melaksanakan permintaan pengguna dengan tujuan tertentu (Supriyanto, 2015: 117). Sedangkan menurut Simamarta (2006: 22) aplikasi adalah program atau sekelompok program yang dirancang untuk digunakan oleh pengguna akhir (enduser). Aplikasi dapat dimanfaatkan untuk keperluan pembelajaran kepada peserta didik mengingat dalam suatu proses pembelajaran seharusnya terdapat interaksi antar komponen-komponen pembelajaran. Salah satu pendekatan pembelajaran yang memungkinkan antara komponen-komponen pembelajaran tersebut adalah pembelajaran interaktif. Pembelajaran interaktif adalah lawan dari pembelajaran tradisional yaitu elemen yang disusun untuk meningkatkan pemahaman konsep secara interaktif dari peserta didik melalui kegiatan berpikir dan bekerja yang menghasilkan umpan balik melalui diskusi dengan petunjuk atau tanpa petunjuk dari pendidik (guru). Berdasarkan uraian di atas, dapat disimpulkan bahwa aplikasi pembelajaran interaktif adalah suatu program yang mengemas sebuah metode pembelajaran berbantuan komputer yang dapat memberikan respons balik terhadap pengguna akhir (peserta didik) dari apa yang telah diinputkan kepada aplikasi tersebut.

\section{Manfaat Multimedia}

Multimedia diartikan sebagai kumpulan dari berbagai peralatan media berbeda yang digunakan untuk presentasi. Setelah tahun 1980-an, multimedia didefinisikan sebagai penyampaian informasi secara interaktif dan terintegrasi yang mencakup teks, gambar, suara, video atau animasi (Soenarto, Jurnal inovasi dan aplikasi teknologi. Volume 9, Nomor 1, Februari: 116). Multimedia dapat digunakan untuk proses pembelajaran sehingga dapat merangsang pikiran, perasaan, perhatian dan minat peserta didik untuk mencapai tujuan belajar. Secara umum multimedia 
pembelajaran memiliki manfaat untuk mempermudah interaksi guru dan peserta didik dan menarik minat peserta didik dalam proses pembelajaran.

\section{Prosedur Pengembangan Multimedia Pembelajaran}

Dalam mengembangkan media pembelajaran berbasis multimedia interaktif diperlukan berbagai cara untuk menghasilkan media yang baik. Salah satunya adalah dengan menerapkan prosedur pengembangan media pembelajaran. Pengembangan media pembelajaran terbagi dalam 6 langkah, yaitu: (1) Menganalisis kebutuhan dan karakteristik peserta didik, (2) Perumusan tujuan instruksional, (3) Perumusan butir-butir materi, (4) Mengembangkan alat pengukur keberhasilan, (5) Penulisan naskah media, dan (6) Mengadakan tes dan revisi (Sadiman, 2016: 100). Menurut Luther dalam Ariesto Hadi Sutopo, terdapat enam tahap sebagai langkah pengembangan multimedia pembelajaran, yaitu concept, design, material collecting, assembly, testing, dan distribution (Sutopo, 2013: 3248).

\section{Multimedia Online}

Media pembelajaran yang tepat digunakan pada masa sekarang ini adalah media berbasis teknologi. Pengertian teknologi sendiri merupakan perpaduan yang kompleks dari manusia dan mesin, ide, prosedur, pengelolaan. Kata teknologi seolah tak lepas dari ilmu pengetahuan karena memang pada hakikatnya teknologi adalah penerapan ilmu atau pengetahuan lain yang terorganisir ke tugas-tugas praktis. Teknologi adalah penerapan sistemik dan sistematik dari konsep ilmu perilaku dan ilmu fisika serta pengetahuan lain untuk memecahkan suatu masalah.

Teknologi Informasi dan Telekomunikasi (Information and Communication Technology/ICT) merupakan tulang punggung aplikasi Web 2.0. Perkembangan Teknologi Informasi dan Komunikasi yang fenomenal dan menjadi awal munculnya aplikasi web adalah Internet. Internet merupakan jaringan global komputer dunia, besar dan sangat luas sekali dimana setiap komputer saling terhubung satu sama lainnya dari negara ke negara lainnya di seluruh dunia dan berisi berbagai macam informasi, mulai dari text, gambar, audio, video, dan lainnya. Internet itu sendiri berasal dari kata interconnection networking, yang berarti hubungan dari banyak jaringan komputer dengan berbagai tipe dan jenis, dengan menggunakan tipe komunikasi seperti telepon, satelit, dan lainnya (Munir M, 2016: 169).

Internet merupakan media teknologi yang multifungsi yang bisa dimanfaatkan dalam dunia pendidikan. Suatu pembelajaran yang memanfaatkan media internet sebagai alat bantu proses pembelajaran dinamakan pembelajaran online, atau juga bisa disebut e-education atau e-leaning atau secara spesifik dalam dunia pendidikan dinamakan model pembelajaran jarak jauh. Istilah e-learning memiliki definisi yang sangat luas. E-learning terdiri dari huruf e yang merupakan singkatan dari elektronik dan kata learning yang artinya pembelajaran. Dengan demikian e-learning dapat diartikan sebagai pembelajaran dengan memanfaatkan bantuan perangkat elektronik khususnya perangkat komputer. Istilah e-learning dapat pula didefinisikan sebagai sebuah bentuk teknologi informasi yang diterapkan dibidang pendidikan 
dalam bentuk dunia maya (Munir M, 2016: 169). Elearning juga dapat diartikan sebagai sebuah program aplikasi berbasis internet yang memuat semua informasi tentang pendidikan seputar pendidikan yang jelas, dinamis, akurat dan up to date serta memberikan kemudahan bagi para pembelajar untuk melakukan pembelajaran secara online (Munir M, 2016: 170).

Secara umum terdapat dua model pengajaran online, yaitu synchronous dan asynchronous. Pada model asynchronous, peserta didik belajar dengan langkahnya sendiri, melihat bahan kuliah dan catatan dan mengambil masukan dari pendidik ketika peserta didik memiliki waktu. Peserta didik berkomunikasi dengan pendidik dan sesama peserta didik melalui chatting, e-mail, dan mengikuti grup diskusi. Peserta didik belajar sesuai dengan kecepatan belajar dan kesibukannya. Hanya tugas dan tes yang biasanya terjadwal mengikuti batas akhir. Sementara pada model synchronous, peserta didik belajar pada kelas maya dalam waktu yang sebenarnya seperti pada kelas konvensional. Pendidik memimpin kelas dengan menayangkan presentasi slide atau para peserta didik dapat melihat pendidik melalui video berbasis web secara langsung. Selain itu model synchronous mengandalkan fitur chatting yang memungkinkan pendidik dan peserta didik berinteraksi sesamanya dan dapat menggunakan saluran pribadi ketika membutuhkan bantuan tanpa mengganggu pengajaran yang berlangsung. Namun keharusan untuk mengikuti pengajaran sesuai dengan jadwal yang telah ditentukan seperti pada kelas konvensional menyebabkan model synchronous kalah populer dibanding model asynchronous dan Behr, http://journal.amikom.ac.id/index.php/informatika/article/download/92/44).

Pembelajaran online atau e-learning merupakan pengembangan dari sistem pembelajaran jarak jauh. Secara umum pendidikan jarak jauh didasarkan pada keterpisahan antara peserta didik dan pendidik dalam ruang dan waktu, pemanfaatan (paket) bahan belajar yang dirancang dan diproduksi secara sistematis, adanya komunikasi tidak terus-menerus (non-continous) antara peserta didik dengan peserta didik, tutor, dan organisasi pendidikan melalui beragam media, serta adanya penyeliaan dan pemantauan yang intensif dari suatu organisasi pendidikan (Pannen, 2013: 17). Sistem pendidikan jarak jauh memiliki atau mempunyai dua komponen yaitu sistem belajar jarak jauh (distance learning) dan sistem pengajaran jarak jauh (distance teaching). Sistem belajar jauh memberikan penekanan kepada peserta didik dan proses belajar (learner-centered), sedangkan sistem pengajaran jarak jauh lebih berfokus pada proses pengajaran, sistem organisasi, dan pengajarnya (teacher and system centered). Sementara itu, sistem pendidikan jarak jauh berfokus pada kedua sisi secara utuh, baik pada peserta didik dan proses belajarnya, maupun pada proses pengajaran, sistem organisasi, dan pengajarnya (Pannen, 2013: 12). Unsur yang harus dimiliki oleh pembelajaran jarak jauh berbasis web, di antaranya:

1. Pusat kegiatan peserta didik; sebagai suatu community web based distance learning harus mampu menjadikan sarana ini sebagai tempat kegiatan peserta 
didik, dimana peserta didik dapat menambah kemampuan, membaca materi pelajaran, mencari informasi dan sebagainya.

2. Interaksi dalam grup; peserta didik dapat berinteraksi satu sama lain untuk mendiskusikan materi yang diberikan oleh pendidik. Pendidik dapat hadir dalam grup ini untuk memberikan sedikit ulasan tentang materi yang diberikannya.

3. Sistem administrasi peserta didik; dimana peserta didik dapat melihat informasi mengenai status peserta didik, prestasi peserta didik dan sebagainya.

4. Pendalaman materi dan ujian; biasanya pendidik sering mengadakan quiz singkat dan tugas yang bertujuan untuk pendalaman dari apa yang telah diajarkan serta melakukan tes pada akhir masa belajar. Hal ini juga harus dapat diantisipasi oleh web based distance learning.

5. Perpustakaan digital; pada bagian ini terdapat berbagai informasi kepustakaan, tidak terbatas pada buku, tetapi juga pada kepustakaan digital seperti suara, gambar, dan sebagainya. Bagian ini bersifat sebagai penunjang dan berbentuk data base.

6. Materi online diluar materi kuliah; untuk menunjang perkuliahan diperlukan juga bahan bacaan dari web lain. Oleh karena itu pada bagian ini pendidik dan peserta didik dapat langsung terlibat untuk memberikan bahan lainnya untuk dipublikasikan kepada mahasiswa lainnya melalui web (Uno, 2016: 39).

Metode belajar jarak jauh dan teknologi informasi bertemu dengan strategi belajar kelas sehingga menciptakan suatu lingkungan baru yang disebut dengan program belajar fleksibel (flexible learning). Program belajar fleksibel ini perlu dicermati karena hal ini merupakan tantangan yang harus segera diwujudkan guna mengantisipasi masa depan. (Zuhairi, 1999: 57). E-learning atau pembelajaran online memiliki kelebihan dan kekurangan. Kelebihan dalam proses pembelajaran online menurut Bates dan Wulf pada tahun 1996 adalah:

1. Meningkatkan interaksi pembelajaran (enchange interactivity).

2. Mempermudah interaksi pembelajaran di mana dan kapan saja (time and place flexibility).

3. Memiliki jangkauan yang lebih luas (potential to reach a global audience).

4. Mempermudah penyempurnaan dan penyimpanan materi pembelajaran (easy updating of content as well as archivable capabilities) (Pannen, 2013: 17).

Kekurangan atau kelemahan dari e-learning adalah:

1. Terpisahnya antara pendidik peserta didik menyebabkan interaksi antara pendidik dan peserta didik kurang maksimal.

2. Teknologi e-learning cenderung lebih terfokus pada aspek teknologinya bukan pada aspek pendidikannya.

3. Proses pembelajarannya cenderung ke arah pelatihan dan kurang memperhatikan aspek afektif.

4. Pengajar dituntut mengetahui dan menguasai strategi, metode, atau teknik pembelajaran berbasis teknologi informasi dan komunikasi yang mungkin belum dikuasai. 
5. Proses pembelajaran e-learning memerlukan motivasi belajar yang tinggi karena dalam praktek pembelajarannya dilakukan secara mandiri. Jika motivasi peserta didik kurang maka proses pembelajaran akan mengalami kegagalan dan tujuan pembelajaran tidak akan tercapai.

6. Tidak semua peserta didik dapat memanfaatkan internet karena terbatasnya fasilitas yang dimiliki.

7. Kurangnya pengetahuan dan keterampilan (skill and knowledge) dalam mengoperasikan computer dan memanfaatkan internet secara maksimal (Munir M, 2016: 174).

Pembelajaran berbasis web merupakan suatu kegiatan pembelajaran yang memanfaatkan media situs (website) yang bisa diakses melalui jaringan internet. Pembelajaran berbasis web atau yang dikenal juga dengan "web based learning" merupakan salah satu jenis penerapan dari pembelajaran elektronik (e-learning).

Web-based learning adalah pengajaran dan pembelajaran yang didukung oleh penggunaan teknologi internet, baik sebagai alat maupun sumber informasi. Definisi tersebut senada dengan yang dikemukakan oleh Munir yang menyebutkan bahwa pembelajaran berbasis web adalah "sistem pembelajaran jarak jauh berbasis teknologi informasi dan komunikasi dengan antarmuka web" (Munir M, 2016: 231). Model pembelajaran ini merupakan salah satu dari model pembelajaran yang bisa diterapkan melalui pemanfaatan e-learning.

Dalam pembelajaran berbasis web, peserta didik belajar dengan cara mengakses sebuah situs web, kemudian melakukan kegiatan-kegiatan pembelajaran seperti mempelajari materi, melakukan evaluasi, mengerjakan tugas, maupun berinteraksi dengan sesama temannya atau berkonsultasi dengan pengajar. Semuanya dilakukan melalui situs web tersebut dan dapat dilakukan secara mandiri ataupun dengan bantuan dari pihak pengajar sebagai fasilitator. Di sini terlihat jelas bahwa peranan situs web e-learning dalam suatu kegiatan pembelajaran berbasis web adalah sebagai media pembelajaran. Hal ini sesuai dengan definisi yang dikemukakan oleh Susilana dan Riyana yang menyebutkan bahwa media pembelajaran merupakan "suatu wadah dari pesan pembelajaran yang disampaikan demi terlangsungnya sebuah proses pembelajaran (Riyana, 2013: 1).

\section{Klasifikasi Pembelajaran Berbasis Web}

Aplikasi-aplikasi web-based learning bisa diklasifikasikan berdasarkan jenis materi/konten yang ada di dalamnya. Ada tiga klasifikasi (Munir M, 2016: 232) sebagai berikut:

\section{Text and Graphic Web-Based Learning}

Web-based learning jenis ini sangatlah sederhana karena hanya menampilkan teks dan grafik/gambar saja sebagai sarana untuk menyampaikan materi pembelajarannya. Keuntungan dari web-based learning jenis ini adalah kemudahan dalam pengaksesannya karena tidak menampilkan konten yang terlalu rumit. Akan tetapi level interaktifitas dari web-based learning jenis ini sangatlah rendah sehingga tidak akan mencapai hasil pembelajaran yang optimal pada peserta didik. 


\section{Interactive Web-Based Learning}

Model interactive web-based learning menyediakan program-program interaktif di dalam webnya. Peserta didik bisa berinteraksi secara mandiri dengan situs web tanpa bantuan dari pengajar/fasilitator. Web-based learning model ini biasanya dilengkapi dengan sarana pembelajaran seperti self-test, text entry, column matching, dan lain-lain.

\section{Interactive Multimedia Web-Based Learning}

Model web-based learning ini memiliki tingkat interaktifitas yang paling tinggi. Selain memuat semua fitur yang telah tersedia pada dua model web-based learning yang telah disebutkan sebelumnya, web-based learning jenis ini juga menyertakan sarana komunikasi real time antara peserta didik dengan pengajar maupun peserta didik lainnya. Sarana komunikasi tersebut bisa berupa video streaming, interactive web discussion, voice over internet protocol (VolP), chatbox dll. Penerapan model web-based learning jenis ini bisa mencakup seluruh kegiatan pembelajaran yang biasa dilakukan di kelas konvensional/tatap muka.

\section{PENUTUP/SIMPULAN}

Multimedia adalah gabungan lebih dari satu media dalam suatu bentuk komunikasi. Multimedia pada masa kini merujuk pada penggabungan dan pengintegrasian media, seperti teks, animasi, grafik, suara, video ke dalam sistem komputer. Akhir-akhir ini konsep multimedia semakin populer dengan munculnya monitor komputer bersolusi tinggi, teknologi video, dan suara serta usaha peningkatan memproses komputer pribadi. Sebagai contoh sekarang sudah terdapat komputer dekstop yang bisa merekam suara dan video, memanipulasi suara serta gambar untuk mendapatkan efek khusus, memadukan dan menghasilkan suara serta video, menghasilkan berbagai jenis grafik termasuk animasi, dan mengintegrasikan semua ini kedalam satu bentuk multimedia.

Kriteria bahan ajar multimedia yang baik yaitu tampilan harus menarik baik dari sisi bentuk gambar maupun kombinasi warna yang digunakan, narasi atau bahasa harus jelas dan mudah dipahami oleh peserta didik. Penggunaan istilah perlu disesuaikan dengan pengguna media agar pembelajaran bisa efektif, materi disajikan secara interaktif, artinya memungkinkan partisipasi dari peserta didik, kebutuhan untuk mengakomodasi berbagai model yang berbeda dalam belajar, karakteristik dan budaya personal dari populasi yang akan dijadikan target, sesuai dengan karakteristik peserta didik, karakteristik materi dan tujuan yang ingin dicapai.

\section{DAFTAR PUSTAKA}

Ashar, Rayandra, (2012), Kreatif Mengembangkan Media Pembelajaran (Jakarta: Referensi Jakarta.

Bukhori, Mochtar (2007), Pendidikan Antisipatoris, Cet. I; Yogyakarta: Kanisius. 
Darmawan, Deni (2012), Teknologi Pembelajaran. Bandung: PT Remaja Rosdakarya. Dragan dan Behr (2001) sebagaimana dikutip oleh Amir F. Sofyan, Perkembangan Perangkat LunakPengelolaanPengajaran Berbasis Web, mimeo, diunduhdarihttp://journal.amikom.ac.id/index.php/informatika/article/dow nload/92/44, diakses pada tanggal 1 Juni 2017.

Munir (2012), Multimedia. Bandung: CV. Alfabeta.

Munir (2016), IT, Pembelajaran Jarak Jauh Berbasis Teknologi Informasi dan Komunikasi, Cet. I; Bandung: Alfabetha.

Pannen, Paulina (2013), Pengertian Sistem Pendidikan Terbuka dan Jarak Jauh, dalam Tian Belawati (Editor, dkk), Pendidikan Terbuka dan Jarak Jauh, (Jakarta: Universitas terbuka, 2013).

Riyana, C. (2013), Konsep Dasar e-Learning, Dokumen Presentasi pada Pembelajaran e-learning di Jurusan Kurikulum dan Teknologi Pendidikan (Fakultas IImu Pendidikan Universitas Pendidikan Indonesia, Bandung 2013).

Sadiman, Arief S. (1986), Media Pendidikan Cet; 1 Jakarta: Rajawali.

Sadiman, Arif S. dkk. (2016), Media Pendidikan (Pengertian Pengembangan dan Pemafaatannya), Cet.1; Jakarta: CV Rajawali.

Simamarta, Janner (2006), Aplikasi Mobile Commerce menggunakan PHP dan MySQL, Cet. III; Yogyakarta: Andi Offset. Janner.

Soenarto, Sunaryo, Pengembangan Multimedia Pembelajaran Interaktif Mata Kuliah Tata Hidang, Inotek: Jurnal inovasi dan aplikasi teknologi. Volume 9, Nomor 1, Februari.

Supriyanto, Aji (2015), Pengantar Teknologi Informasi, Cet. VII; Jakarta: Salemba Infotek.

Sutopo, Ariesto Hadi (2013) Multimedia Interaktif dengan Flash, Edisi I, Cet. 1; Yogyakarta: Graha IImu.

Syah, Muhibin (2012), Psikologi Pendidikan Dengan Pendekatan Baru, Cet. II; Bandung: PT. Remaja Rosdakarya.

Uno, Hamzah B. (2016), Model Pembelajaran Menciptakan Proses Belajar Mengajar yang Kreatif dan Efektif, Cet.4; Jakarta: Bumi Aksara.

Wijaya, Kusumah (2015), Pengertian Media Pembelajaran.Diakses dari http://media-grafika.com/pengertian-media-pembelajaran pada tanggal 24 Feb 2015, Jam 116.30 WIT.

Zuhairi, Aminudin (1999), Model-Model Pendidikan Terbuka dan Jarak Jauh, dalam Tian Belawati, dkk (Editor), Pendidikan Terbuka dan Jarak Jauh, (Jakarta: Universitas Terbuka. 